Brazilian Journal of Political Economy, vol. 30, $n^{\circ} 3$ (119), pp. 381-400, July-September/2010

\title{
Global booms and busts: How is Brazil's middle class faring?
}

JAN PETER WOGART*

Brazil's Post War economic history has been marked by inflationary booms and busts, which kept large parts of the population poor, as income distribution remained highly skewed, and most governments failed to put enough efforts and resources into education and health. That seems to have changed recently, as an increasing number of studies have shown considerable advances in the incomes of the lower and the middle classes. This essay examines those findings and puts them into a historical perspective, discussing earlier attempts and hopes of Brazilian policy makers to advance the welfare of the population. It concludes that while the last fifteen years have been remarkable for the country to achieve macroeconomic stability and while the increasing efforts of supporting the poor seemed to have been moving income distribution slowly towards a more equal level, there is still a long way to go. The 2008 world financial crisis also hit Brazil hard, but the recovery has been smoother and faster than in any OECD country. The impact of the current crisis may provide a good test as to the robustness of the previous trends to further the wellbeing of the poor and the middle class

Keywords: Brazil income distribution; middle class incomes; poverty.

JEL Classification: D31.

\section{INTRODUCTION}

Social scientists concerned with Latin America have studied and discussed issues of global and regional imbalances and their impact on income and wealth distribution for a long time (Rodrick, 2001). They have been wondering why a

\footnotetext{
* Professor of Economics and Finance at the University of Applied Sciences Bremen, and Sr Research Associate, The German Institute for Global and Area Studies (GIGA), Hamburg. E-mail: wogart@gmx. net. The author would like to thank Gilberto Calcagnotto and Michael Stahl for many helpful comments and suggestions. Submitted: January 2009; Approved: March 2009.
} 
subcontinent so rich with natural resources and gifted people has been unable to advance as forcefully as the majority of Asian countries, which — though having fewer natural resources and where large populations started out substantially poorer and less educated - have made significant advances in reducing poverty and furthering a rapidly increasing middle class during the last five decades. To the critics surprise that development seems also now to have occurred most recently in a few Latin American countries, among them Brazil.

In a special report of its February $14^{\text {th }}, 2009$ issue, The Economist focused on that "Burgeoning Bourgeoisie" in developing countries in general and the large emerging economies in particular. Basing the analysis on a number of recently published studies by economists and sociologists on income growth and distribution in those economies, the analysis happily concluded that $50 \%$ of their population had now reached a "middle class status" (Ravallion, 2009; Wilson and Dragsanu, 2008; Bhalla, 2002 and 2009). By setting the lower limit of the middle class to start at US\$2 per day (in purchasing power parity) may be a low base for what traditionally is considered middle class status and attitudes. It was nonetheless remarkable that most of the studies had come out with similar results, and there was no doubt that the first years of the new millennium had been not only very good ones for the Asian giants China and India, but also for other countries around the globe, among them Brazil.

In the latter country's case, the news is particularly welcome, since Brazil's economic growth in the post War period has often been accompanied by increasing income inequality. Several recent studies of Brazilian researchers at IPEA and the Getulio Vargas Foundation are not only signaling the surge of the middle class, but also find that income distribution has continuously improved during the last 15 years.(de Barros et al., 2007, 2008; Neri et al., 2008). Their statistics show that almost $52 \%$ of households now earn between 1,064 and 4,591 Brazilian Reais a month, roughly equivalent to US\$ 625 and US\$2,700, and with it have moved into what they call the "C" class. ${ }^{1}$ In addition, income distribution improved consistently though slowly as shown by its basic indicator, the GINI coefficient, which fell from over 0.6 to close 0.55 between 1993 and 2007 .

Because of its heterogeneity and the difficulty in properly identifying the middle class (MC), less has been researched and written on their behalf than on the poorest segments of the population. That seems to have changed now, providing an ideal base for several considerations as to the rise, fall and rise again of the middle class in a country which has always been more interested in the growth and expansion of its economy than the allocation of resources and the distribution of the generated income. While considering income distribution issues, this study will concentrate on the MC and its major characteristics, its growth and expansion in Brazil over the last fifty to sixty years in general and its most recent experience in

\footnotetext{
${ }^{1}$ The "C" stands for "casa, carro, computador, crédito e carteira de trabalho", attributes which a good part of the new middleclass participants are still striving for, as discussed later.
} 
particular, which is closely linked to the natural resource boom and bust in the first decade of the 2000s. While intrigued by the results of the most recent studies about the rise of the Brazilian MC, it is not only the 2008-09 world recession which makes us wonder to which extent many of those who seemed to have arrived are again fallen back closer to the poverty line, but we will also attempt to show that the girating pattern of economic activity and the high income inequality which have characterized the rise and fall of many middle class families in the last 50 years is not necessarily a phenomenon of the past.

We will start with a discussion of the major ways of measuring who does and who does not belong to the MC and to what extent a subdivision into the upper "global" and the lower "emerging" MC is useful. We will then examine its post war establishment and and rapidly changing development of the MC, with emphasis on the last 15 to 20 years of a more stable framework, taking a closer look at the most recent past, characterized by the boom and bust in world commodities and financial markets. In that context we will not only examine the potential pressures emanating from globalization, but also consider particular characteristics of the Brazilian socio-economic and legal system, which continue to hamper economic and social mobility. ${ }^{2}$ Before having a brief look at the possible implications of the 2008-2009 world financial and economic crisis on the future wellbeing of the middle class, we also have a look at what can be considered a "typical" middle class fate of a Brazilian family and their ups and downs during the last 50 years.

\section{MEASURING THE MIDDLE CLASS}

If one considers the fate of the middle class in a country, the simplest procedure is to take the median and then decide how large the percentage of people on both sides of that median should be. In his contributions to analyze America's shrinking middle class, or better the earnings of those people considered middle class in the 1970s and 1980s, MIT's Lester Thurow took the group lying between 75 and $125 \%$ of the median (Thurow, 1986). William Easterly took a slightly broader spectrum in a later study, including two fifth of the income earners on each side of the median (Easterly, 2001).

Nancy Birdsall followed the same approach as Lester Thurow; concentrating on the $50 \%$ around the median in the case of developing countries in general and Brazil in particular (Birdsall, 1996, 2000a). Different from the American case, however, her and her colleagues research is first and foremost interested in the critical assessment of income distribution patterns and differences in third and first world countries, being concerned over past developments and worsening trends of

\footnotetext{
${ }^{2}$ While that analysis requires a broader framework, we will limit our observations to a few contributions of sociologists and political scientists, and we will only touch on the political implications of the middle class' changing fortunes in the last decades.
} 
income distribution in both. In the case of Brazil, their findings have been very useful, and we will discuss them in some detail below.

One of the problems of the above mentioned studies are the comparability of median incomes of rich and poor nations. ${ }^{3}$ Consumption patterns and attitudes should differ considerably of middles class families in the USA with a per capita income of over US $\$ 46,000$ vs. Brazil with a per capita income of barely $\$ 6,000 .{ }^{4}$ In addition, while one study may be more interested in wage earners, the other one may find that without getting hold of good estimates of earnings in the informal sector, no useful information on middle class earnings can be derived. For that reason, the more recent studies have concentrated on absolute figures to discuss and compare middle classes around the world.

The largest number of researchers have chosen to establish a bottom floor for the middle class, by including everybody's earnings above the daily poverty limit of US\$2 a day and then going up to US\$12. Another group has started with the latter amount and stopped at around $\$ 50$, since that range reflected the average of the respective incomes in Brazil and Italy (Milanovic and Yitzaki, 2001). In that study the middle class of the emerging economies was estimated to have reached 250 million in the year 2000, and is expected to grow to 1.2 billion people in 2030 . Large as those figures would seem in absolute terms, they amounted to only $6 \%$ of the world population in 2005 and are expected to be $15 \%$ in 2030 . That group could then be considered to be the upper or "global" middle class.

Those 250 to 300 million are closely watched by the multinational corporations, their banks and their consultants, and it is therefore no surprise that both McKinsey and Goldman Sachs staff have provided studies which focus on the target populations of those corporations' products and services (Beinhocker et al., 2007; Wilson and Dragusano, 2008). However, even those surveys recognize the multiple layers of the middle classes, and they divide them into subgroups, providing them with such fancy names as the "the globals, the strivers, the seekers and the aspirers." In the large emerging countries, such as China, India and Brazil, the first two groups amount to over 100 million, providing valuable and rapidly growing markets for quality products.

It is, however, the lower middle class which covers the majority of the teaming populations in these countries, and they are also under scrutiny by researchers who have concentrated on poverty studies. In independent assessments Martin Revallion from the World Bank and Surjit Bhalla from one of the most prestigious Indian research organization came to very similar conclusions, as they looked at the world's new entrants into the middle class within the last 15 years (Ravallion, 2009;

\footnotetext{
${ }^{3}$ That does not mean that it cannot be done fruitfully as the 2000 Working Paper by Birdsall et al shows.

${ }^{4}$ World Bank (2008). Gross national income per capita 2007, Atlas method, World Development indicators data base, Washington D.C. In: http://siteresources.worldbank.org/DATASTATISTICS/ Resources/GNIPC.pdf, access: 9.3.2009
} 
Bhalla, 2009). By using the definition of putting families earning between US $\$ 2$ to $\$ 13$ per day in 2005 purchasing power parity (PPP) into the middle class, they found that this class had grown from close to 1 billion people in 1990 to over 2.6 billion in 2005, with most of that rapid expansion taking place in China (from 174 to 800 million) and India (from 147 to 264 million people).

\section{BRAZIL'S MIDDLE CLASS DEVELOPMENT IN THE LAST 50 YEARS}

In the past, Brazil has been in the forefront of income and wealth inequality, a characteristic for which many of other Latin American countries also have been known for some time. Discussed in numerous studies, analysts have held this inequality responsible for serious economic and social problems which have plagued Latin America over decades (Birdsall, 2007; Medeiros, 2005; Ferreira and de Barros, 2004). That inequality is still only too obvious today. Brazil's Gini coefficient, which had risen from 0.6 in the mid 1990s to 0.63 in 2003, fell to 0.58 in 2008 according to some studies and to 0.55 at others (Paes de Barros et al., 2007-8, pp. 134-35; Neri et al., 2008, p. 20). ${ }^{5}$ While inequality has decreased continuously over the last 15 years, this decline would still seem rather small, especially if one considers the efforts the Cardoso and Lula governments have undertaken to provide poor families with direct cash payments (Bolsa Família) and the increasing educational and job opportunities for the lowest quintile of the population, developments which have occurred in recent times in the context of a relatively stable macroeconomic environment.

While there have been spurts in industrial development and economic growth, comparable to that experienced in the emerging economies of Asia, Brazil's average industrial output expansion has been less than spectacular. Between 1960 and 2005, average industrial output advanced barely $4 \%$ a year, similar to the industrial sectors of Mexico and the Philippines. That expansion was less than half the growth rates of several East Asian economies, such as China, South Korea, Thailand and Vietnam and less than the modest industrial output growth in the South Asian economies of India and Pakistan. ${ }^{6}$ There have been, however, a number of spurts since WWII when Brazil's economy surged at three different periods, with GDP growing quicker (above $5 \%$ ) for at least 5 years in a row, leaving a definite impact on the middle class.

The first wave of an enthusiastic spurt occurred between 1956 and 1961. After the relatively short post war boom in the late 1940s and early 1950s, the simultaneous government programs to build Brasília and open up the West, providing generous financial support to the North Eastern region and accelerating the

\footnotetext{
${ }^{5}$ Earlier studies had found very similar Gini coefficients in the 1970s and 1080s, fluctuating between 0.57 and 0.62 (IBGE, various years).

${ }^{6}$ World Bank, World Development Indicators, several years.
} 
import substitution industrialization process by inviting the major global automobile multinationals to produce in Brazil's South, President Kubitschek made it possible to harmonize national with regional goals, and he initiated, induced and implemented large public sector and foreign private investments. The consequence was a boom in real output expansion, which however went hand in hand with accelerating inflation between 1956 and $1961 .^{7}$

By 1962, however, it became clear that this model of development was not sustainable, as the "aspiring" urban masses of blue and white collar workers realized that their wage adjustment lagged behind the furious rise in prices, and as the state and local government escaped any federal control in cutting back on their expenditures. With the 1946 Constitution granting Congress and the states substantially enlarged rights, the newly elected President faced fierce opposition. Although hailed as a leader against corruption and waste, he gave up soon before even trying to establish some degree of order into the economic disruptions and the volatile political process. By leaving the job to the vice president, the political situation worsened, as the new president tried his luck by mobilizing the "urban proletariat" and with it frightening the middle class, the conservative part of which was calling for military intervention. ${ }^{8}$

While statistical evidence is less abundant than in more recent times, there is no doubt that during the first 15 postwar years, Brazil's middle class expanded. The opening up of new opportunities in so many different regions of the country had a substantial impact on social mobility and rapidly rising expectations. Sociological studies about the intergenerational mobility during those times are mixed. While a 1968 study suggests that "correlational analysis suggested that Brazil had rates of mobility that were rather low compared to some other countries (Kahl, 1968, p. 174), a more recent study states unequivocally in 1996 that "Brazil has witnessed an extended period of social mobility, with most individuals moving upwards in relation to their fathers during the 1950-1980 era" (Pastore and Zyberstajn, 1996). ${ }^{9}$ Of what we can deduct from the income distribution data, it is clear that the Gini coefficients were decreasing from 0.63 in 1945 to 0.57 in the 1960 s, i.e. they moved together with rapidly rising economy. However, they were back to over 0.6 in the early 1970 s and remained at that level during the unstable 1980s until the early 1990s.

As hyperinflation threatened to bring Brazil close to an economic standstill and a potential social revolution in 1963-64, the military intervened. That action

\footnotetext{
${ }^{7}$ The phenomenon of achieving simultaneous real output growth with inflation led to the "Structuralist-Monetarist debate for over one decade. See O. Campos (1968).

${ }^{8}$ At the same time as other Latin American leaders south of Brazil's borders followed similar lines of action, they also faced resistance from the "global" middle class, marching in the streets and using their empty cooking pots as protesting drums.

${ }^{9}$ The author distinguishes two periods. While there was all around upward and outward mobility between the 1950s and 1970s, the recent decades of the last century were characterized more by horizontal mobility, i.e., increasing move of Brazilians to the Western frontier.
} 
followed patterns of earlier interventions, which were justified by the military seeing itself as arbiter in a political system in which the three branches of the legislative, executive and the judicial powers seemed to be in a deadlocked battle which threatened the stability and security of the country. The first years of the monetary and fiscal stabilization program were accompanied by belt tightening and slow growth. That changed in 1967 , when pragmatic policies tried again to combine economic expansion with "managed" inflation at a moderate and controlled level. Through cunning macro management, Brazil's economy took off one more time and registered high economic growth to an extent that analysts spoke of a "Brazilian economic miracle." 10

That optimism got a serious damper, when the first results of the household surveys were signaling again a deterioration of income distribution (Fishlow, 1971). As time went on, even the military leaders had to admit that while the economy was doing rather well, the people did not. As the adjustment to the world oil crisis started to hit the enlarged energy importing industrial sector, leading to considerable cost increases, which industrialists attempted to shift to wholesalers, retailers and consumers. That led to again the fight for higher income shares, and social unrest started all over the country, fueled not only by the economic malaise but also the increased unhappiness with the stern military leadership. As to the fate of the middle classes, it would seem that the period saw again less upward social mobility and more horizontal mobility, caused by substantial migration particularly to the Amazon region, which the military governments had furthered with new infrastructure projects to protect the northern and western frontiers of the country.

Before discussing the third and most recent period of more stable and eventually also more sustainable expansion, it needs to be made clear that Brazil weakening rate of economic growth during the 1980s was accompanied by little if any improvements in basic health and education parameters. In that context, it has been pointed out that the inequality of income distribution is closely related to the low levels of providing crucial public services. Recent research has maintained that those disappointing outcomes during the earlier years were first and foremost a consequence of policy failures, such as neglect of basic health care for the poor (McGuire, 2001). The combination of macroeconomic stabilization and emphasis on the crucial public services of health and education of the Cardoso and Lula administrations (1994-2008) has shown how serious efforts in improving those basic services within a low inflation economic environment will be rewarded by both, better income distribution and higher economic growth.

Brazil's economic and growth record of the last 15 years is shown in Graph 1, reflecting another phase of economic expansion in the early to mid 1990s, which - after a short interruption caused by the contagion of the Asian and Russian fi-

\footnotetext{
${ }^{10}$ The miracle man was Professor Delfim Neto, who became Finance Minister in 1967 until 1971.
} 
nancial crises - resumed in 2000 and accelerated in the most recent years until 2008. It is important to note that during that time agriculture was the most dynamic sector, enjoying averaging growth rates of over $4.5 \%$ in the last few years, while industry grew by a modest average of $2.4 \%$ in the $1990 \mathrm{~s}$ and advanced by a slightly improved $2.9 \%$ in the first five years of this decade. ${ }^{11}$

Graph 1: Brazil GDP growth rates, 1990-2006

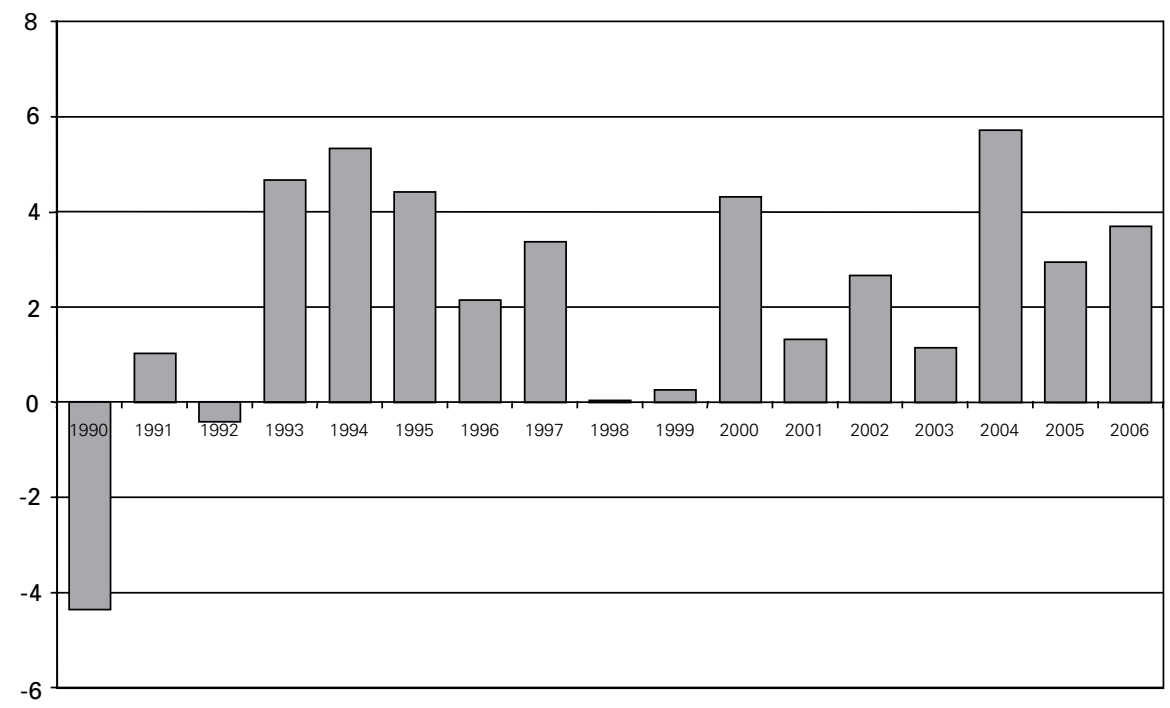

Source: World Bank, Brazil — Partnering for Results (2008)

As stated earlier, a number of studies have confirmed that since 1990, there has been a gradual and nearly uninterrupted decrease in inequality, as highlighted in Graph 2. ${ }^{12}$ The explanations are manifold, but three characteristics stand out. The first is the simultaneous reduction of inflation and resumption of economic growth. The second is increased attention and allocation of funds to the education and health sectors, with emphasis on basic health services, particularly if one includes the expensive HIV/AIDS campaign under basic health provision. Finally, a broad application of a special transfer program to poor families (Bolsa Família) by the Lula government, following an initiative by his predecessor Cardoso in 2001-2002 program. That program improved the lives of a substantial number of poor people. Beyond providing for food and shelter it improved their access to education and health facilities.

\footnotetext{
${ }^{11}$ World Bank, World Development Indicators, 2008. Industrial output in 2006-2008 are estimated to have been around $4 \%$.

${ }^{12}$ Neri et al. (2008), IPEA, World Bank.
} 


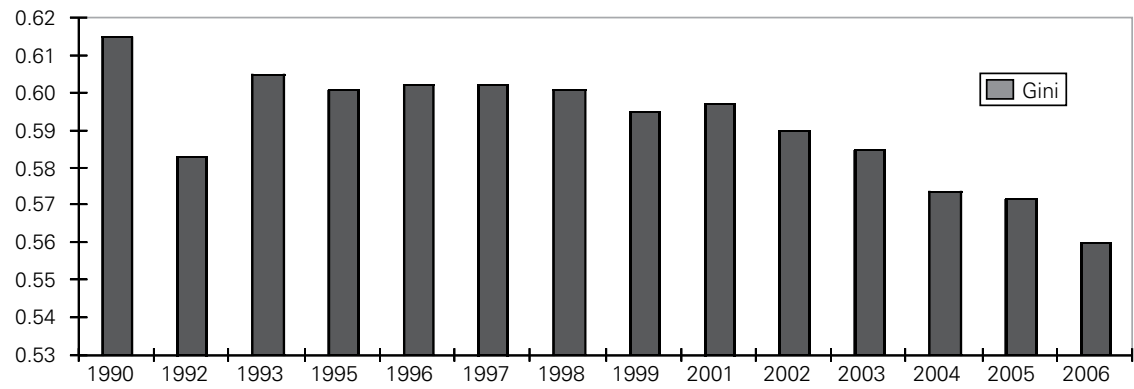

Source: Neri et al. (2008)

Not surprisingly poverty has decreased substantially, gradually in the 1990s and more rapidly in the most recent decade, from close to $35 \%$ of the population in 1992 to $18 \%$ in 2007. This development is highlighted in Graph 3, which compares the average growth of the 10 income groups of the Brazilian population between 2001 and 2006. As shown clearly, the poorest segment of the population saw their incomes advance by an average of $9 \%$, and the next $30 \%$ of the population by an average over $5 \%$ p.a. While those gains diminish as we move up the income ladder, only the top $20 \%$ had advances below the national average. As a consequence, the Gini coefficients of the last few years have decreased significantly.

Graph 3: Average growth rate of household income

by decile of income distribution during 2001

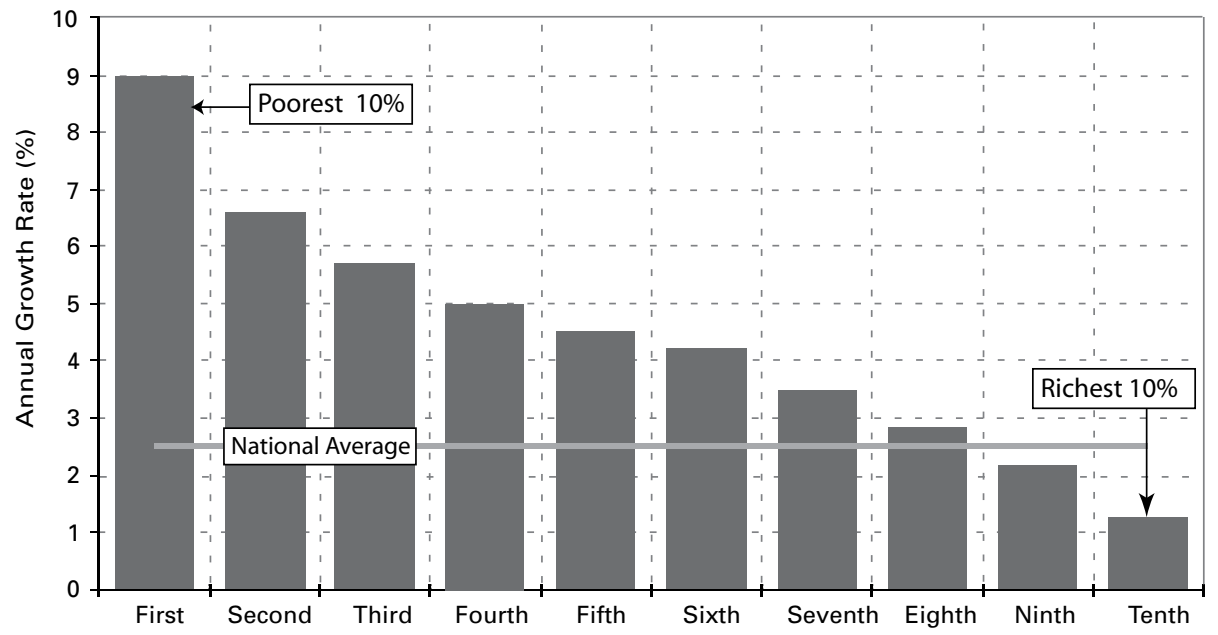

Source: World Bank (2008). Brazil — Partnering for Results

So, how has the Brazilian middle class fared in those last few years? Apparently not bad at all, if one takes the three groups between the fourth and the sixth 
deciles of Graph 3, averaging income growth was $4.5 \%$ p.a., which was $2 \%$ percentage points above the national average. Those findings are also confirmed by the researchers of the Getulio Vargas Foundation, who computed an accumulated income gain of close to $50 \%$ for the lowest income decile, averaging over $30 \%$ for the fourth, fifth, and sixth deciles, and declining to $6.7 \%$ to the top $10 \%$ between 2000 and 2007 (Neri et al., 2008).

As shown above, the middle classes seemed to have participated in those significant gains of the recent past. This is particularly obvious in the year 2007, in which the groups of the $1^{\text {st }}$ and the $10^{\text {th }}$ deciles actually registered declines, while the $5^{\text {th }}, 6^{\text {th }}$ and $7^{\text {th }}$, gained most, averaging $5.5 \%$. If one concentrates on the absolute incomes of households and individuals, the choice becomes more arbitrary, since one has to start with the decision about which income allows people to live a life without the constant threat of hunger and disease. Most researchers have therefore started to count all those people as middle class, who have escaped poverty, i.e., earning more than the equivalent of US $\$ 2$ (purchasing power parity) a day. It becomes more difficult to draw the upper limit, but there is some agreement to take an amount between 4 to 5 times the low entry base. Since there are a lot of people between those two boundaries, multiple subdivisions have been undertaken, the simplest of which is just to divide between the lower middle and upper middle class. As Table 1 indicates for the 1990s, those middle incomes in Brazil were not only substantially below the MC incomes of the OECD countries but also below the transition economies and also slightly less than the Latin American average, where income distribution has been similarly uneven for the last 50 years.

Table 1: Middle Income Strata in the 1990s (In US\$)

\begin{tabular}{l|c|c|cc}
\hline \multicolumn{1}{c|}{ Country } & GNP per capita & $\begin{array}{c}\text { Household } \\
\text { Average }\end{array}$ & \multicolumn{2}{c}{$\begin{array}{c}\text { Middle Income } \\
\text { Strata Thresholds }\end{array}$} \\
\hline High Income & 18,775 & 10,909 & 6,935 & 11,558 \\
Transition Economies & 5,555 & 3,632 & 2,732 & 4,552 \\
Latin America & 7,200 & 4,697 & 1,649 & 2,764 \\
Brazil & 6,250 & 4,563 & 1,326 & 2,211 \\
\hline
\end{tabular}

Source: Birdsall et al. (2000a)

The Brazilian researchers separated the Brazilian population into five groups, with the middle class " $\mathrm{C}$ " household receiving between 1064 and 4591 Reais per month and the per capita earnings ranging between 282 and 1218 Reais, equivalent to between 9.4 and 40 Reais per day or US\$ 4 and 20 at current exchange rates. For the average household it would mean an average income between US\$ 20 and 75. This definition resembles the one used by the authors of the Goldman 
Sachs study, which starts with US\$ 15 per household entering the middle class and leaving it at US\$ 72 (Goldman Sachs, 2008). ${ }^{13}$

According to the Brazilian household surveys, the "C" class rose from just over $30 \%$ to close to $50 \%$ of the Brazilian population between 1991-92 and 2007-2008. That would mean in absolute terms from 46 to nearly 95 million Brazilians, half of whom have entered the market place for durable consumer goods, ranging from mobile phones, radios, TVs and DVD consoles to refrigerators, freezers and more often than not motor bikes and cars in the last 10 to 15 years. While a large number of them still live in favelas, the houses are made of brick and most of them now have access to running water and - of course - electricity in order to use all those electric and electronic goods. There is a leap of the $\mathrm{C}$ class expansion in the last 15 years, averaging $2.5 \%$ during the reign of President Cardoso, and accelerating to $4 \%$ during the years of the Lula administration, perhaps not surprising for a former union leader turned politician.

While The Economist reported that "Brazil has greatly expanded the number of jobs in the formal sector", this might have happened in the boom years 2007-2008, but there seems less of that in earlier years, the record of which is mixed. The unemployment rate stayed around $9 \%$ during the whole decade, and while that was below the $11 \%$ to $12 \%$ rate a decade earlier, it was still very high. The changes of the various income sources of Table 2 are also hinting towards less dynamism in the wage/salary earning sector than in the one reporting "other" sources of income. Average growth of wages and salaries was just over $2 \%$, while income from social security rose by 5\% between 1993 and 2007, which brought up the overall average to $2.6 \%$ for the last 15 years.

Table 2: Composition of Income by Class and Changes 1993-2007

\begin{tabular}{|c|c|c|c|c|c|c|}
\hline \multirow[b]{2}{*}{$\begin{array}{l}\text { Income } \\
\text { by class }\end{array}$} & \multirow[b]{2}{*}{ Total } & \multirow{2}{*}{$\begin{array}{c}\text { bottom } \\
50-\end{array}$} & \multirow{2}{*}{$\begin{array}{c}\text { next } \\
40\end{array}$} & \multirow{2}{*}{$\begin{array}{l}\text { top } \\
10\end{array}$} & \multicolumn{2}{|c|}{ Changes (\%) } \\
\hline & & & & & 1993-2007 & 2001-2007 \\
\hline $\begin{array}{l}\text { All Sources } \\
\text { (Reais) }\end{array}$ & 526.3 & 155.3 & 540.7 & 2178.9 & 2.6 & 2.5 \\
\hline Work (\%) & 76.8 & 76.1 & 76.3 & 77.4 & 2.2 & 2.3 \\
\hline $\begin{array}{l}\text { Social } \\
\text { Security (\%) }\end{array}$ & 19.5 & 17.1 & 21.1 & 18.8 & 5.0 & 3.3 \\
\hline $\begin{array}{l}\text { Social Programs } \\
(\%)\end{array}$ & 1.7 & 5.5 & 1.1 & 1.1 & -0.7 & 13.5 \\
\hline $\begin{array}{l}\text { Private } \\
\text { Transfers (\%) }\end{array}$ & 2.0 & 1,3 & 1.5 & 2.7 & 4.2 & -2.3 \\
\hline
\end{tabular}

Source: CPSD/FGV

\footnotetext{
${ }^{13}$ A monthly sum of US\$2000 per household is quickly spent by a middle income family on such basics as food, housing, utilities, education, and health. It is therefore not surprising that analysts would use group "B" as the actual upper or global middle class, whose minimum income is US\$ 2000 and more.
} 
In all three classes listed in Table 2 (50 is representing the lowest $50 \%$ of income receivers, 40 characterizes the middle income receivers and 10 are the top ten income receivers) income earned as compensation for work made up about three quarters of total income received with social security and social programs following with over $20 \%$. What is more interesting to note are the changes of each category, with social security payments increasing more rapidly than wage income, not exactly a sign of exuberant job creation. In addition, the $13.5 \%$ increase of the social programs between 2001 and 2007 are linked to the already mentioned Bolsa Família, which were initiated in 2002.

Based on the exciting findings of the emergence of a strong and ambitious middle class, several surveys have been undertaken to get an impression on the future expectations of that middle class. The Getulio Vargas Foundation initiated a Future Happiness Index of young people between 15 and 29 in a number of both developing and OECD countries. With a top note being set at 10 points. The Brazilian youth scored highest at 8.8 , followed by Venezuela and Denmark (Neri et al., 2008). At the bottom are Haiti, Paraguay, surprisingly Cambodia, and not surprisingly Zimbabwe.

A review on life satisfaction undertaken by the Pew Research Center for The Economist came to similar results (The Economist, 2009, p. 11). The Latin American middle classes are definitely more satisfied at this point in time than their comrades in Eastern Europe or Africa, and even in some of the Asian booming markets like India and Malaysia middle class people seem to be more circumspect. In all countries, however, the middle classes are significantly more satisfied than the lower classes, many of whom are not yet ready to believe in the miracle of economic and social advancement. ${ }^{14}$

\section{BRAZIL'S MIDDLE CLASS MICROCOSM: HAPPINESS AND RESIGNATION}

Individual interviews, which many reporters of Western press agencies have had with the "new" middle class, seem to echo the above survey findings. One of those was BBC's Gary Duffy reporting from the Paraisópolis favela in São Paulo. One of the town's old timers, who had been running a grocery store for over 30 years, maintained that there had been a noticeable and definite improvement in recent years: "Salaries have improved a little and the quality of life as well", he explained and continued "because we don't have inflation any more, it is easier to get credit and there are more opportunities to buy things, such as fridges, televisions, microwaves and some people have cars that are almost new. It is improving." His neighbor, a 26 year old man, who had a job in stacking shelves, agreed. He had

\footnotetext{
${ }^{14}$ This contrasts with Hirschman's assessment in the 1970s, when he predicted that Brazil's rising inequality had reached its limits leading to socio-political disasters. (Hirschman and Rothschild 1973, 561).For further consideration of Hirschman's view see discussion below
} 
been in his job for four years and started with nothing. Now he has a TV, a DVD console, of course his little "house" in the favela, and he is thinking of buying a car in the not too distant future.

That sounded too good to be true and will now be severely tested as the global financial and economic crisis also hits Brazil. At the time of writing this paper (mid-2009), it is too early for any detailed study, but two different assessment of the first phase of the crisis in late 2008 have been undertaken (Jornal do Brasil, 2009; Neri, 2009).

According to the researchers of the PNP Paribas Bank, the "C" class lost nearly 2 million people in 2008 , mostly by people joining the lower classes "D" and "E". While substantial in absolute numbers, in percentage terms that loss was marginal, lowering the "C" class participation in the Brazilian urban economy from $46 \%$ to $45 \%$. According to Neri, the "C" class has expanded since the crisis, partly because quite a number of the upper classes " $A$ " and " $B$ " joined the "C" class. However, at the same time, less people remained in the lower classes "E" and "D". The big losers were the upper classes, which would lead to the conclusion that income distribution has continued to improve further, even after the crisis hit the country.

Journalists have also been on the run and - among others - they report from the Amazonas capital of Manaus. More than in other urban centers that city boomed during the last few years one more time, particularly since its free port status brought in lot of footloose industries producing anything from first class electronic goods, by Sony and Honda, Yamaha and Sanyo, Panasonic and LG from East Asia and Kodak, Xerox and Philips from the U.S. and Europe. Those factories imported basic and intermediate inputs from their homeland to be converted to finished consumer goods in the free port zone. They provided jobs and purchasing power, but have now drastically reduced their production and had to let many people go (Der Spiegel, 2009).

While President Lula encouraged people to continue consumption before $\mathrm{X}$-mas 2008, credit became scarcer by the day, and with most Brazilians buying even low cost durable consumer goods on credit, consumption fell. What is, however, revealing of the story is the fact how resilient this newly emerging middle class seems to be. As jobs in the shiny factories got scarce, people reverted to go back to their friends' or parents' shops and produce low cost consumer goods such as shoes and sandals; or they were going to places where they find cheap products - particularly textiles - and selling them in places where prices were still a bit higher. In sum, they seem to be determined to also overcome the latest crisis, particularly, since this time, it is not a Brazilian made crisis and the national banking sector is in better shape than many of the ones in the OECD countries.

In contrast to the optimism and resilience of the emerging Brazilian middle class, there are countless stories of declining middle class fortunes, linked not always to globalization pressures but also to problems which still plague the legal framework, the economic system and the social climate, all of which seem hard to be removed. Although some progress has been made on several fronts with 
better economic management, critical areas in administration and bottlenecks in infrastructure have remained over the last 50 years in Brazil. Among them are: (a) high taxes and low quality of public spending, (b) elevated real interest rates, (c) a rather complicated set of business rules, which make it difficult and time consuming to open up shop and conduct business, (d) inflexible labor legislation leading to attempts to circumvent the system and favor informal business, and (e) insufficient funding and lack of quality in infrastructure investment. A family saga in Box 1 shows how these issues can become highly relevant in peoples' careers and lives.

Box 1: Brazilian middle class up-and downward movements: A family saga

The following story reflects the above mentioned problems Brazilian middle class people have been facing some of which they have been unable to overcome. The setting is a typical middle class family with 8 children in the 1950s, with both parents (secondary education) working in government jobs; he as a higher official at the social security office, she has a teacher in a school for disadvantaged children. With education being considered crucial, all children are going to Catholic schools, and five of them continuing at universities, with three of the boys studying engineering and the daughters specializing in geography, history and psychology. In the "miracle" years of the late 1960s, all of them are successful in their relative occupations, with the daughters occupying university positions and the oldest son being in charge of an electrical engineering company involved in building Brasília, the second as a project engineer at a foreign multinational, the third running a successful automobile dealership, and No. 4 working as a highway engineer for the government. The times are good, the expectations are high and so are the consumption levels. These people are clearly part of the global middle class, with two of the daughters actually moving to the USA to teach and research and finally staying there and getting married. All of them are enjoying a substantially higher standard of living than their parents at that point in time.

20 years later, the situation looks very different. The pressure of their respective jobs has had tragic consequences for two of the sons, who die before getting 60 . In the first case, the above mentioned problems with labor legislation caught up with the oldest one in the electric engineering firm, which had neglected to pay part of the high social security fees for many years and was faced with inflation adjusted fees and penalties, requiring the firm to close. Attempts to open a new business failed, because of legislation requiring at least 5 years of waiting before engaging in a new enterprise. In the second case, multinational management in Brazil learned fast not to keep people firmly employed for too long a time and put the second son to work as a consultant for project work at the age of 55, a job which turned out to be both more stressful and insecure. While strong smoking may well have played a part in the sudden heart attack, there was no doubt that the changing job situation contributed to the pre-mature death.

The fate of the other two boys is not enviable either. During the high inflationary times during most of the 1960s, 70s and 80s Brazilians were quick to engage in all kind of transactions which tried to escape the rapid devaluation of the currency. That was 
particularly true in the car business, in which all kinds of schemes were invented to keep selling cars to consumers with doubtful credit worthiness. In short, the auto business overextended, after one of the many stabilization attempt had changed the rules of the game in credit and debt payments in the car business, the shop was out of business and so was No.3, unable to recover because of similar problems to get a second chance within a reasonable period. Last but not least No. 4's employment with the government did not work out as planned. As the government had the engineer hire worker for highway projects asking him to pay for the crews to do the preparatory work and repaying him much later at devalue currency for outlays which had been financed through credit. In short, the surviving sons are now finding themselves to be close to the poverty line and need support from the rest of the extended family.

The sisters have done better. This time one of them benefitted from Brazil's extravagant transfer payment system. Having taken care of the parents entitled her to receive the social security pension when her father died. While it meant to give up her job as a principal of a high school in order to receive that pension, it was lucky for her and the rest of the family to have that basic source of stable and rather generous financial support. Not surprisingly, those social securities pensions were the fastest increasing shares of the Brazilian middle class families' incomes, as shown in Table 2. In short, it enabled the children of the impoverished brothers to attend good schools and get a solid education. As to the next generation, there is not yet a pattern of upward or downward movement clearly visible, except that the generation has to adjust to even greater insecurity and that few if any of them has reached the living standards of their parents of earlier years. In addition, that generation has been suffering from even greater insecurity, as street crime, which has dramatically increased over the last decades, has affected them already as children.

Source: N.R. Tragow (2008) "The not so 'Beautiful Horizon' of Belo Horizonte: Family Histories in Minas Gerais," mimeo.

\section{GLOBALIZATION: CHANCES AND RISKS OF BRAZIL'S MIDDLE CLASS}

In his famous study on "The Changing Tolerance for Income Inequality in the Course of Economic Development" Albert Hirschman maintained that most people in developing countries will not mind if incomes of other people will rise rapidly as long as their own has a chance to grow too, though it may not do so at a point in time (Hirschman and Rothchild, 1973). By introducing the "tunnel effect" he called on economists and social scientists who had described that experience in a number of developing countries. However, he warned that there will be disasters in countries in which "ruling groups and policies makers fail to realize that the safety valve, which the effect implies, will cease to operate" (ibid., p. 561) $\mathrm{He}$ maintained that among Latin American countries, Brazil and Mexico had already experienced those disasters, and that possibilities were increasing for many more to come.

Twenty five years later, the theme of getting trapped in a tunnel was again invoked by a group of social scientists. In their study "Stuck in the Tunnel: Is Glo- 
balization Mudding the Middle Class?” Birdsall, Graham and Pettina examined four globalization challenges, which seemed to have particularly affected the middle classes of the emerging economies: They include the changing role of the state, increased volatility and vulnerability of the world economy, top driven inequality and the globalization of consumption standards. While that essay is providing examples of other countries than Brazil to highlight the importance of the pressures emanating from those global forces, the fate of a good part of the Brazilian middle class would seem to have been affected similarly to those discussed in that essay and will therefore be treated here in some detail.

In the midst of the present world financial crisis government is back being involved in areas it thought that it would be managed better by private sector participants. However, that has not meant renewed hiring or re-hiring of public sector officials let go earlier during times of privatization. While it is true that the Brazilian government has maintained an important stake in several sectors, such as energy, pharmaceuticals and banking, reductions in the civil service and privatization of some large public enterprises have led lower public sector employment since the late 1980s. Similar to other South American countries, the loss of public sector jobs in Brazil was not compensated by the gains in formal private sector employment, leading to increased unemployment.

Parallel with the shift from public to private sector employment, there was also an increase in "unprotected" jobs in Brazil, where worker have neither a written contract nor social benefits. While not quite as drastic as in Argentina, the share of unprotected jobs increased by 5 percentage points from 63.6 to $68.5 \%$ in the late 1980s and early 1990s (Rodrik, 1999). Apparently, that development changed to the better in the most recent boom years and has contributed to the optimism reported above. However, for those middle class workers and employees who were cut off from previous benefits being already in the labor force twenty years earlier, this was too little too late.

Not enough that the diminished public sector employment opportunities squeezed the people who had believed that they had life long protection, public expenditures have shifted increasingly from subsidizing middle classes in cities and towns to focus on the poor in urban and rural areas. No wonder that an ever increasing number of middle class members shifted their votes towards socialist candidates, which in Brazil led to the election of Lula in 2002, after he had been defeated three times earlier on. While the President's large scale income transfer program to the poor helped only a number of them to enter the middle class, the earlier discussion made clear that the recent economic policies have benefitted almost all middle class families.

Another pressure point beyond job security with decreasing public sector employment has been the increased global volatility and with it the difficulty of financial planning. Banking and currency crises are not new to Brazil, and observers have been amazed about the relative smooth landing of the economy after the devaluation and financial crisis in 1998-99. However, Brazil has now for many years been the country with the highest real interest rates in the world, a way to keep inflation 
at bay and attract foreign capital. While large enterprises and wealthy individuals could borrow abroad at low interest rates, for small middle class business that was not possible. The fate of our automobile dealer of Box 1 has been repeated many times in Brazil, when the shift from often negative real interest rates to high positive ones occurred overnight. Entry into new business with little capital has been made very difficult in the last 20 to 30 years, even as the development banks and the rise of microfinance institutions have been able to help here and there.

The impact of the current financial and currency crisis has still to be felt and measured, but it again symbolizes Brazil's exposure to the volatility of global private capital flows. There was already a significant increase of that volatility in the 1990s and one can expect that to happen again by the end of this decade..$^{15}$ While a few financial wizzards may have benefitted from this increased volatility, the majority of middle income earners have not, and it is indeed so typical for the positive attitude of the newly emerging middle classes in the recent past, how much emphasis they put on stability, first and foremost of every day prices, which also includes predictable and relatively stable exchange rates.

The above sources of old and renewed pressures on the middle class are rather direct and can be expressed in monetary units. That is not the case with increases in relative insecurity through two trends which are closely connected. The first has a long history in sociological studies in the U.S. and became known under the "keeping up with the Jones" slogan. The second one is related to what one has called "top driven inequality." It occurs in countries where income distribution between the middle classes (e.g., two thirds around the median income) and the upper classes (top $10 \%$ to $20 \%$ of income receivers) widens.

This phenomenon has been observed particularly in the USA, where the incomes of the "winner take all mentality" of CEOs, media and sport stars have increasingly outstripped the incomes of their less famous and fortunate colleagues. For Latin America in general and Brazil in particular, attempts to measure that stress came to negative results. ${ }^{16}$

The globalization of consumption standards plays a vital role in the ambitions of Brazilian middle class families, especially among the younger members. As mentioned earlier, the multinationals and their consultants are eagerly researching the purchasing desires and patterns of the middle classes, since those have been the most rapidly expanding markets for companies like Nike, McDonald, Sony and many other giants of both durable and non durable consumer goods. Different from the earlier pressures from volatility and state withdrawal, those pressures increase at prosperous times and lead to rapidly increasing demand for credit, which even the high interest rates in Brazil are unable to stop. It is then no surprise that despite the elevated interest rates, here was a surge in private sector debt in the last few years.

\footnotetext{
${ }^{15}$ Private capital flow volatility was 0.009 in the 1980 s and rose to 0.040 in the 1990 s, surpassing the average of other Latin American countries World Bank, World Development Indicators, CD-ROM.

${ }^{16}$ See Birdsall et al. (1999).
} 


\section{SUMMARY AND CONCLUSION}

This study has attempted to evaluate the many positive results of recent income growth and prosperity of the Brazilian population in general and the emergence of a new middle class in particular, followed by a more detached long run view of middle class social mobility in Brazil. Contrary to previous periods of strong primary goods export expansion, the recent global export boom has been found to be more beneficial for people in the emerging economies, first and foremost for the newly emerging middle class, with a considerable amount of previously poor people having moved upwards to achieve middle class status as defined by both absolute and relative measures. However, while the favorable external circumstances played an important role - in other words not suffering from Dutch disease but enjoying Chinese charm - it has been pointed out that a shift to vastly improved macro- and microeconomic policies in Brazil laid the groundwork for income growth, which should become sustainable in the years to come, if the world economy is on its way back to recovery.

The recent downturn has been indeed the making of the rich countries, which none of the emerging countries were able to escape, although their financial system have been maintained much better than bank management in most OECD countries. In that context it was found that while the dependence on global economic events and its strong impact on the Brazilian economy had a more serious effect on members of Brazil's expanding middle class than either the upper or lower classes in the past, investigations of the most recent crisis are disagreeing of which part of the population suffered most. Agriculture has played a major role in Brazil's growth in the last fifteen years. While also dependent on global trade, it would seem that the strength of that sector my be less immune to industrial and financial service crises. In short, the probability of newly arriving members of the middle urban classes suffering losses may be the ones to examine more closely.

It would seem that while not exactly "rags to riches" stories, there seem to have been many cases of considerable upward mobility in the last 15 years than there have been cases of impoverishment of middle class people and families in the slow growing late 70s and 80s, when globalization and liberalization hit the developing countries hard. The reason we have included a case study is to realize that many persons and their families have been experiencing both during their lifetimes. For some that volatility and stress can be lethal, for others it will be just a way of life they will have to cope with and hope that their children will achieve what they were unable to do.

Brazil's great economist and economic historian Celso Furtado has maintained in a recent essay that the new generation must be better prepared to cope with major challenges, since they will have to preserve the historical legacy of national unity, while continuing with further building a democratic society. As the growth potential of the domestic market is substantial, there is room for co-operation with the technology still controlled by foreign groups, but "Brazil will only survive as a nation if it develops into a juster society and maintains its political independence" 
(Furtado, 2000, p. 11). The growth and strength of the middle class should indeed serve and support those two goals.

\section{REFERENCES}

BACHA, E.L. and TAYLOR L. (1978) "Brazilian income distribution in the 1960s: Tacts' model results and the controversy", Journal of Development Studies. 14 (3): 271-297.

DE BARROS, R.P. et al., eds. (2007 and 2008) Desigualdade de Renda no Brasil: Uma Analise de Queda Recente, Rio de Janeiro: IPEA, volume 1 and volume 2.

DE BARROS, R. P.et al. (2009) Measuring Inequality of Opportunities in Latin America and the Caribbean, New York: Palgrave McMillan and the World Bank.

BEINHOCKER E.D. et al. (2007) “Tracking the growth of India's middle class”, The McKinsey Quarterly, 3: 51-61.

BHALLA, S.S. (2002) Imagine there's no Country: Poverty, Inequality, and Growth in the Era of Globalization. Washington D.C., The Peterson Institute of International Economics.

BHALLA., S.S. (2009) “The middle class kingdoms of India and China.” Mimeo.

BIRDSALL, N. and R.H. SABOT (1996) Opportunity Foregone: Education in Brazil. Washington D.C.: Inter-American Development Bank

BIRDSALL N., GRAHAM, C. and PETTINATO, S. (2000a) "Stuck in the tunnel: Is globalization mudding the middle class?” The Brookings Institution Center on Social and Economic Dynamics Working Paper No. 14

BIRDSALL, N. (2000b) “Building a market friendly middle class”, $12^{\text {th }}$ Annual World Bank Conference on Development Economics. Proceedings. The World Bank, Washington D.C.

BIRDSALL, N. (2007) “Why globalization doesn't lift all boats”, Boston Review, March/April.

CAMPOS, R. (1967) Reflections on Latin American Development. Austin: University of Texas Press.

CARDOSO E. et al. (1995) "Inflation and unemployment as determinants of inequality in Brazil: The 1980s”, in Dornbusch R. and Edwards. S., eds., Recovery and Growth: Latin America and the Middle East. Chicago: The University of Chicago Press for NBER.

DATT, G. and RAVALLION, M. (1992) "Growth and poverty in rural India and Brazil”, Journal of Development Economics, 38: 275-95.

DER SPIEGEL (2009) “Die Krise errreicht Brasiliens Amazonas region”, March 10.

DUFFY, G. (2009) “Brazil sees middle class emerging” BBC News. http://newsvote.bbc.co.uk/mpapps/ pagetools/print/ news.bbc.vo.uk/2/hi/business/6993546.stm.

THE ECONOMIST, (2009) "Burgeoning bourgeoisie", A special report on the new middle classes, February $14^{\text {th }}$, London.

EASTERLY, W. (2001) “The middle class consensus and economic development”, Journal of Economic Growth, 6 (4): 317-335.

FISHLOW, A. (1972) "Brazilian size distribution of income", American Economic Review, May 1972: 391-402.

FURTADO, C. (2000) "Brazil: options for the future", Cepal Review 70, 7-11.

GRAHAM, C. and FELTON, A. (2006) "Inequality and happiness: insights from Latin America", Journal of Economic Inequality, 4 (1): 23-41.

HIRSCHMAN, A.O. (1973) "Changing tolerance for income inequality in the course of economic development”, Quarterly Journal of Economics, 87 (4): 544-566.

HOLZMAN, F.D. (1950) "Income determination in open inflation" Review of Economics and Statistics, 32 (2): 150-158.

JORNAL DO BRASIL (2009) "Crescimento da classe media é interrompido" $2^{\text {nd }}$ of July, A19.

KAHL, J.A. (1968) The Measurement of Modernism. Austin: University of Texas Press.

LANDES, D. (1998) The Wealth and Poverty of Nations. New York: Norton. 
LANGONI, O. (1973) Distribuição da Renda e Desenvolvimento Econômico do Brasil. Rio de Janeiro: Fundação Getúlio Vargas.

MCGUIRE, J.W. (2001) "Democracy, social policy, and mortality decline in Brazil," Paper prepared for $23^{\text {rd }}$ Congress of the Latin American Studies Association.

MILANOVIC, B.and S. YITZHAKI (2002): "Decomposing world income distribution: does the world have a middle class?", Review of Income and Wealth. Blackwell Publishing, 48 (2): 155-178.

MORLEY, S. (2000) "The effects of growth and economic reform on income distribution in Latin America”, CEPAL Review, 71: 23-40.

NERI, M.C. and J. CAMARGO (2001) "Distributive effects of Brazilian structural reforms", in Bauman R., ed. Brazil in the 1990s: a Decade in Transition. London: Palgrave MacMillan.

NERI, M.C. et al. (2008) Poverty and the new middle class in the decade of equality. www.fgv.br/cps/ desigualdade version 1 and 2, Rio de Janeiro Fundação Getúlio Vargas;

NERI, M.C. (2009) "Crônica de uma crise anunciada”, Conjuntura Econômica, March: 50-53.

PASTORE J. and H. ZYBERSTAJN (1996) "Social mobility: The role of education in determening status", in Birdsall, N, and R.H. Sabot, eds., Opportunity Foregone: Education in Brazil. Washington D.C. InterAmerican Development Bank.

RAMOS, L. (1993) A Distribuição de Rendimentos no Brasil 1976/85. Rio de Janeiro. IPEA

RAVALLION, M. (2009) “The developing world's bulging (but vulnerable) 'middle class", World Bank Policy Research Working Paper No. 4816

RODRIK, D. (2001) "Why is there so much economic insecurity in Latin America?", CEPAL Review 73: 7-30.

SUPLICY, E. M. (2002) Renda de Cidadania: A Saída é pela Porta. São Paulo: Cortez Editora/Fundação Perseu Abramo.

THUROW, L.C. (1986) “A general tendency towards inequality”, American Economic Review, May.

WILSON D. and R. DRAGUSANU (2008) "The expanding middle: The exploding world middle class and falling global inequality", Global Economic Paper No.170, Goldman Sachs.

WORLD BANK (2007) Global Economic Prospects. Washingon, The World Bank.

WORLD BANK (2008) Gross national income per capita 2007, Atlas method, World Development indicators data base, Washington D.C. In: http://siteresources.worldbank.org/DATASTATISTICS/ Resources/GNIPC.pdf, access: 9.3.2009. 